УдК 903.2

DOI: https://doi.org/10.33782/eminak2020.1(29).377

\title{
ЕПІГРАВЕТТ СХІДНОГО ПРИКАРПАТТЯ ТА ЕПІГРАВЕТТ І СХІДНИЙ ЕПІГРАВЕТТ В ІСТОРИЧНОМУ РОЗВИТКУ
}

\author{
Микола Оленковський \\ Незалежний дослідник (м. Херсон, Україна) \\ e-mail: molenkovsky@bigmir.net \\ ORCID: https://orcid.org/0000-0003-3382-5263
}

\begin{abstract}
У статті наводяться узагальнені висновки щодо розвитку культурно-історичних процесів в епіграветті Східної Європи. Аргументується соціально-історична база походження класичного епіграветту Східної Європи у Східному Прикарпатті (на території України та Молдови) та його поширення у межах Правобережної України. Наводяться дані щодо походження й історичного розвитку східного епіграветту. Надається аналіз східного епіграветту Лівобережної України за окремими археологічними культурами. Висловлюється погляд щодо впливу як класичного, так і східного епіграветту на формування фінального палеоліту та початку мезоліту Східної Європи.
\end{abstract}

Ключові слова: Пізній палеоліт, класичний епіграветт, східний епіграветт, археологічна культура, крем'яна індустрія

У даній статті містяться лише підсумкові висновки автора щодо історії епіграветтського населення Східної Європи. Переважно це стосується історикокультурних процесів - утворення соціально-історичними людськими спільнотами так званих археологічних культур і поширення їх носіїв просторами Східноєвропейської рівнини. Наслідки археологічних аналізів і наукова аргументація наведені в опублікованих тематичних монографіях автора1.

Згідно до наукових поглядів автора, на базі тривалого розвитку культурних традицій східно-граветтського населення у Східному Прикарпатті утворилися перші виразні культури класичного епіграветту Східної Європи². Археологічні дослідження надають підстави стверджувати, що надалі частина населення залишилася у цьому регіоні, інша ж частина звідси розселилася просторами південно-західної частини Східноєвропейської рівнини.

Аборигенним східно-прикарпатським епіграветтським населенням впевнено можна визнати носіїв ранньобистрицької епіграветтської культури ${ }^{3}$ Етноісторичне співтовариство носіїв індустрійних традицій цієї археологічної культури сформувалося на території сучасної Східної Румунії, між Карпатським хребтом і річкою Прут, найвірогідніше біля 19 тисяч років тому4.

3 сильним похолоданням льодовикового піку Вюрм III населення Східного Украї-

\footnotetext{
1 Оленковский Н.П. Эпиграветт Восточной Европы. Культурно-исторический аспект. Херсон, 2008. 432 с.; Оленковский Н. Эпиграветт Восточной Европы. Методология исследований и конкретноисторические реконструкции. Херсон: Айлант, 2017. 147 с.

2 Оленковский Н.П. Эпиграветт Восточной Европы. Культурно-исторический аспект. С. 31-66.

3 Ibid. C. 128-130.

${ }^{4}$ Chirica V. The Gravettian in the East of the Romanian corpathians. Jassy, 1989. 240 p.; Chirica V. Le Gravettien en Roumanie // Le Paleolithique et le Neolithique de la Roumanie en contexte. Jasi, 1991. S. 715.
} 
нського Прикарпаття, носії традицій східного граветту, почало просування на південь та на південний захід. Водночас, між 20 та 18 тисячами років тому, у Середньому Подністров'ї продовжувало мешкати місцеве населення завершальної фази розвитку своєрідної пізньомолодівської археологічної культури. Однак, тим східнограветтським населенням, яке просунулося униз по Дністру, було утворено на півночі Молдови, біля 19 тисяч років тому, дійсну ранньоепіграветтську археологічну культуру - косоутську. Важко встановити як довго носії цієї археологічної культури мешкали саме у регіоні Молдовського Середнього Подністров'я, але за радіовуглецевим датуванням цей термін міг тривати до 2 тисяч років 5 .

Проведений аналіз археологічних джерел дозволяє автору зробити висновок, що контактування у регіоні Прута епіграветтського населення Середнього Подністров'я (скоріш за все носіїв косоутської епіграветтської культури) та представників ранньобистрицької епіграветтської культури призвело до утворення культурноісторичного угрупування (общини) носіїв виділеної свого часу автором прутосіретської епіграветтської культури ${ }^{6}$. Відбулося це, найвірогідніше, біля 18 тисяч років тому. У подальшому простежується розвиток культурно-історичних традицій населення цієї культури протягом до 3 тисяч років.

Аналізуючи у цілому класичний епіграветт Східної Європи автор прийшов до висновку, що між 19 і 18 тисячами років тому одна з хвиль відтоку населення з Українського Східного Прикарпаття (найвірогідніше вихідці з Середнього Подністров'я) досягли регіону Нижнього Побужжя, де у них склалася специфічна ранньоепіграветтська культура мисливців на бізонів, представлена стоянкою Анетівка II.

Важливо зазначити, що конкретно-історична інтерпретація різних сторін життя носіїв косоутської й анетівської культур є складною задачею. На сучасному етапі археологічних досліджень подальша історія носіїв цих культурно-історичних феноменів простежується тільки узагальнено. Фактично ці археологічні культури виглядають як «яскраві спалахи» на загальному епіграветтському східноєвропейському фоні, з дуже складною для сучасного розвитку археологічної науки можливістю розуміння генетичного походження та їх подальшою історико-культурною спадковістю. Однак у автора є підстави вважати, що утворення цих археологічних культур належить вихідцям з Українського Прикарпаття. Важливо, що ці культури є ранніми, одними з самих давніх культур класичного раннього епіграветту Східної Європи.

Першим культурно-історичним проявом класичного епіграветту Українського Прикарпаття була, як це уявляється на археологічних джерелах сучасного етапу наукових досліджень, дністровська ранньоепіграветтська археологічна культура ${ }^{8}$. Утворено її, скоріш за все, аборигенним населенням, у Середньому Подністров'ї. Можливою причиною виникнення цієї культури є повернення до регіону Українського Східного Прикарпаття населення з більш південних територій Молдовського Подністров'я, що узгоджується з початком незначного потепління після 18 тисяч років тому. Подальша історія мисливців, носіїв цієї археологічної культури, пов'язується як з територією Середнього Подністров'я (у межах й України, й Молдови), так і з пе-

\footnotetext{
${ }^{5}$ Коваленко С.И., Кетрару Н.А. Некоторые особенности развития верхнепалеолитических индустрий в днестровской зоне Молдавии // Stratum plus. Санкт-Петербург, Кишинев, Одесса, 1999. № 1. С. $168-195$.

6 Оленковский Н.П. Эпиграветт Восточной Европы. Культурно-исторический аспект. С. 126-128.

7 Оленковский Н. Эпиграветт Восточной Европы. Методология исследований...

8 Оленковский Н.П. Эпиграветт Восточной Европы. Культурно-исторический аспект. С. 42-66.
} 
ріодичним просуванням на схід - до середньої течії Південного Бугу (багатошарова пам'ятка Володимирівка). Що, скоріш за все, було викликане традиційними міграціями північного оленя (тварини, що була основною мисливською здобиччю носіїв дністровської епіграветтської культури).

У другій половині етапу розвитку класичного раннього епіграветту населення східно-прикарпатського походження, вірогідно через носіїв анетівської археологічної культури, просунулися ще далі на схід - південний схід. У регіоні Нижнього Дніпра утворило нову матеріальну культуру, яка відома за пам'ятками нижньодніпровської епіграветтської культури ${ }^{9}$. Носії цієї археологічної культури заселили також Надпоріжжя та Північне Присивашшя. Судячи з наявних даних (у т.ч. радіовуглецевим датам) населення нижньодніпровської епіграветтської культури мешкало на цих землях між 17 і 15 тисячами років тому. Займалося тут полюванням на бізона та на плейстоценового коня. За даними археологічного аналізу носії цієї археологічної культури були витіснені або знищені біля 15 тисяч років тому прийшлим зі сходу східно-епіграветтським населенням північно-приазовської археологічної культури.

Можна впевнено стверджувати, що етноісторичне походження населення західної частини Східної Європи - носіїв класичного пізнього епіграветту - тісно пов'язане з попереднім населенням класичного раннього епіграветту цієї частини території Європи.

У автора не викликає сумнівів, що виразна пізньоепіграветтська археологічна культура - оселівська - була утворена, вірогідно біля 15 тисяч років тому, населенням Середнього Подністров'я. Можна стверджувати, що відбулося це саме на базі матеріальної культури носіїв попереднього місцевого раннього епіграветту. Основним базовим компонентом цього процесу можна впевнено визнати дністровську епіграветтську культуру. Однак, в складенні оселівської епіграветтської культури приймала участь, найвірогідніше, й специфічна індустрія типу верхніх шарів пам'ятки Молодове V (у цілому ранньоепіграветтська, що відноситься, скоріш за все, до кінця розвитку раннього епіграветту у Середньому Подністров'i). На це вказує наявність в оселівській епіграветтській культурі деяких культуровизначаючих типів знарядь, які відсутні у дністровській культурі, але є в індустрії верхніх шарів Молодове $\mathrm{V}$.

Пізньоепіграветське населення Середнього Подністров'я представлене оселівською епіграветтською культурою10. Існувало в цьому регіоні (з періодичним розповсюдженням на схід, до Південного Бугу) до 13/12 тисяч років тому.

Археологічні джерела надають аргументовані свідоцтва на користь того, що у Румунському Східному Прикарпатті, протягом тривалого часу розвитку класичноепіграветтських індустрій, мешкало населення місцевого походження. Судячи з аналогій, що є як у пруто-сіретській, так і в ранньобистрицькій культурах, пізньобистрицька культура могла утворитися в результаті поєднання традицій носіїв обох зазначених культур. Відбувався цей процес біля 16-15 тисяч років тому. Етноісторичний розвиток населення цієї культури припадає на весь етап пізнього епіграветту та заходить в етап фінального епіграветту Східної Румунії. Завершується цей розвиток

\footnotetext{
9 Оленковский Н.П. Нижнеднепровская эпиграветтская культура // В эпоху мамонтов. Stratum Plus. 2003-2004. № 1. Санкт-Петербург, Кишинев, Одесса, Бухарест, 2005. С. 307-333; Оленковский Н.П. Эпиграветтская стоянка Дмытривка. Херсон: Айлант, 2009. 100 с.

10 Оленковський М. Оселівська епіграветтська культура // Матеріали і дослідження з археології Прикарпаття і Волині. Вип. 9. Львів, 2005. С. 194-216.
} 
біля 12 тисяч років тому. У подальшому нащадки носіїв традицій пізньобистрицької культури стали базовим населенням для утворення специфічного раннього мезоліту Південно-Східного Прикарпаття.

Можна висловити досить обгрунтоване припущення, що у другій половині раннього епіграветту та в пізньому епіграветті населення класичного епіграветту Східного Прикарпаття мігрувало також на північ - у регіони Північно-Західної та Північної України. Відбувалося це, найвірогідніше, епізодично - у періоди потеплінь (між 17 та 13 тисячами років тому).

Дещо іншою уявляється причина появи епіграветту в регіоні Нижнього Подністров'я. В Українському Східному Прикарпатті, перш за все у Середньому Подністров'ї, протягом від 30 до 19 тисяч років тому мешкало населення - носії традицій граветтського шляху розвитку, у тому числі, й східного граветту центральноєвропейського походження. Нижнє ж Подністров'я та Північне Причорномор'я увесь цей час було заселено носіями традицій орін'якського шляху розвитку. Скоріш за все просування пізнього східно-граветтського населення униз по Дністру, біля 20-18 тисяч років тому, призвело не тільки до витіснення епіорін'якського населення на південь, але й до утворення якогось стикового населення - з елементами різноетнічних традицій у матеріальній культурі.

Лінія розвитку орін'яко-епіорін'якського населення на півдні Середнього Подністров'я та на Нижньому Дністрі чітко простежується за пам'ятками Клімауці I, Клімауці II (нижній шар), Клімауці II (верхній шар), Рашків VIII (епіорін'якські шари), Рашків VII11. Вірогідно не є помилкою передбачення, що у формуванні специфічного нижньодністровського епіграветту (з елементами епіорін'яку) приймало участь і саме нижньодністровське населення, представлене індустріями з орін'якськими елементами місцезнаходжень Лапушна й Отарик ${ }^{12}$. Відчутною кількістю епіорін'якських елементів відзначається матеріальна культура населення нижньодністровської ранньоепіграветтської археологічної культури. Носії традицій цієї культури мешкали у Нижньому Подністров'ї, судячи з археологічних аналогій, між 18 і 16 тисячами років тому.

У невеликій кількості є епіорін'якські елементи й у аккаржанській археологічній культурі ${ }^{13}$. Можна припустити, що це зменшення епіорін'якських елементів пояснюється дещо більш молодим віком Великої Аккаржі по відношенню до пам'яток нижньодністровської культури.

Важливо зазначити, що процес утворення матеріальної культури з елементами як епіорін'яку, так й епіграветту (з переважанням других) простежується також й у Північному Причорномор'ї. Відбувалося це у відтинку часу між 20 і 18 тисячами років тому. Й відбувалося, скоріш за все, через якісь контакти місцевого епірін'якського та прийшлого граветтійського населення ${ }^{14}$. Представлене це явище

\footnotetext{
11 Коваленко С.И., Кетрару Н.А. Вказ. пр.

12 Оленковский Н.П. Эпиграветт Восточной Европы. Культурно-исторический аспект. С. 240.

13 Борзияк И.А. Рашковская, аккаржанская и анетовская позднепалеолитические культуры на Юго-Западе СССР // Труды научн. конф. «Проблемы первобытной археологии Северного Причерноморья». Херсон, 1990. С. 18-20.

14 Оленковський М.П. Культурно-історичні процеси в пізньому палеоліті та мезоліті Присивашшя // Археология и этнология Восточной Европы. Одесса, 1997. С. 103-112; Оленковский Н.П. О пути развития одной из групп позднепалеолитических памятников Приазовья // Каменный век: от Атлантики до Пацифики: Замятнинский сборник. Вып. 3 / Рос. акад. наук, Музей антропологии и этнографии им. Петра Великого (Кунсткамера). Санкт-Петербург, 2014. С. 211-220.
} 
такими археологічними пам'ятками, як - стоянка Амвросіївка й Амвросіївське кістковище (амвросіївська культура) ${ }^{15}$, стоянки Нововолодимирівка II та ПершоПокровка I (нововолодимирівська культура)16. Однак пізніше, в епіграветті, епіорін'якські елементи у матеріальній культурі населення Північного Причорномор'я не простежуються.

Автор вважає, що археологічні джерела достатньо обгрунтовано доводять інакше генетичне походження культур граветтського шляху розвитку усього історикокультурного масиву східного епіграветту по відношенню до походження історикокультурного масиву класичного епіграветту 17.

Не викликає суттєвих сумнівів загальне походження східного епіграветту на базі східної гілки східного граветту, що мав розвиток у центрі Східної Європи (у регіонах Десни та Верхнього Дону).

Історія походження та наступного тривалого розвитку східно-епіграветтського населення центральної частини Східноєвропейської рівнини (деснянськоверхньодонського регіону) безсумнівно пов'язана саме з цим районом. Це доводиться наведеними автором результатами проведеного типологічного аналізу археологічних джерел. Аналіз надає можливість стверджувати, що історична спадковість дійсно мала місце. Відтак й обгрунтованими є висновки про місцеве етнокультурне походження населення цього регіону, носіїв східно-епіграветтських традицій в матеріальній культурі. Однак, очевидними є й суттєві відмінності між узагальненими культурними традиціями населення обох етапів. Що й надає можливість вбачати розшарування культурно-історичних традицій місцевого населення за двома самостійними історичними пластами - східний граветт і східний епіграветт. За теперішнім розумінням історичних процесів, відбувся цей перехід з настанням піку останнього холодного стадіалу Вюрм III. Й пов'язано це, перш за все, зі змінами клімату, що призвело до низки змін у складі здобичі та мисливському й побутовому інвентарі палеолітичного населення.

Для матеріальної культури представників східного епіграветту деснянськодонського регіону сумарно властиві - розвинута пластинчаста техніка, що базується на стандартизованих призматичних нуклеусах; категорійно спрощений набір знарядь; значне кількісне переважання різців над скребками; абсолютне переважання бічного типу над іншими типами різців; переважання серед скребків стандартних знарядь кінцевого типу без бічної ретуші, на відщепах і коротких пластинах; наявність виразних мікропластинок з притупленим краєм, що представлені відносно незначною пропорцією; поширеність пластинок зі скошеним кінцем; незначна представленість вістер з притупленим краєм (у т. ч. граветтоїдних, але за наявності вістер мікрошательперрон і мікрокоттес); слабка представленість долотовидних знарядь ${ }^{18}$.

15 Кротова О.О. Граветтоїдні комплекси Північного Причорномор'я // Археологія. 2000. № 2. С. 3037.

16 Оленковский Н.П. Поздний палеолит и мезолит Нижнего Днепра. Херсон, 1991. С. 118-123; Оленковський М.П. Палеоліт та мезоліт Присивашшя: Проблеми епігравету України. Херсон: Придніпров'я, 2000. С. 33-48; Оленковський М.П. Культурно-історичні процеси в пізньому палеоліті та мезоліті Присивашшя...

17 Оленковський М.П. Епіграветтські та східноепіграветтські культури України // Vita Antiqua. 2001. № 3-4. С. 149-155.

18 Оленковский Н.П. Эпиграветт Восточной Европы. Культурно-исторический аспект. С. 338-358. 
Підтверджується це й висновками деяких колег-археологів, які зазначають, що: «Виділення за техніко-морфологічними критеріями двох хронологічних груп пізньовалдайських пам'яток дозволяє знайти точки дотику граветтоїдних і більш пізніх комплексів, намітити динаміку розвитку крем'яного інвентарю. Схожість крем'яного інвентарю Мізина з граветтоїдними знарядійними наборами Борщево I i Костьонок 21, реалістична жіноча статуетка та мергелева пластика Єлісеєвичів I, знаряддя типу ножів «шательперрон», іноді з ретушованою основою, що зустрінуте у більшості ранніх комплексів (варіант аносівсько-гмелінських і пушкарівських вістер) вказують на деяку спадковість обох етапів КІО мисливців на мамонтів. Ця спадковість, однак, як це не парадоксально, фіксується лише на окремих розрізнених ознаках явно різнокультурних пам'яток, начебто граветтійський «спадок» поділено між численними спадкоємцями»19.

Дійсно, населення цього регіону, на хронологічному відрізку 19-18 тисяч років тому, остаточно втратило залишки граветтійських традицій віллендорфськокостьонківського типу в матеріальній культурі. У цей самий період в матеріальній культурі місцевого населення формуються елементи індустрій раннього східного епіграветту. У ці ранньоепіграветтські індустрії переходять деякі специфічні та визначальні типи знарядь та технологічних засобів від індустрій найпізніших проявів матеріальної культури східного граветту. Ще переважає виготовлення знарядь на відносно великих пластинах. Серед типів знарядь успадковуються: специфічні вістря на пластинах з дуговидно притупленим краєм, прямокутники серед пластинок 3 притупленим краєм, значне переважання різців над скребками, абсолютне домінування серед різців бічних знарядь, наявність поодиноких відносно коротких подвійних скребків, долотовидні знаряддя.

На етапі ж пізнього східного епіграветту, представленого тут деснянською археологічною культурою, відбувається типологічне спрощення матеріальної культури. Знаряддя виготовляються вже на середніх і дрібних заготовках. Вістря з дуговидним притупленим краєм і прямокутники часто виготовляються на мікропластинках. Стають малочисельними долотовидні знаряддя. Подвійні скребки тільки короткі.

Деснянське населення, носії традицій раннього східного епіграветту, відоме нам за декількома стоянками з різнотипною матеріальною культурою. Це, перш за все, пам'ятки - Мізин, Єлісеєвичі I, Юровичі, а також Єлісеєвичі II. До кінцевого етапу раннього східного епіграветту тут, найвірогідніше, відносяться стоянки Супоневе, Косиця та Коршеве II. В індустріях цих пам'яток простежуються як риси схожості, так й відмінності. Їх практично неможливо об’єднати в одну археологічну культуру. При цьому, спільних рис між ними значно більше, ніж спільних рис з іншими одночасними стоянками Східної Європи. Знаючи, що общинні традиції у матеріальній культурі формуються не одномоментно, можна впевнено передбачати, що у майбутньому будуть виявлені дослідниками стоянки однокультурні й до цих пам'яток. Тільки тоді з'явиться можливість проведення обгрунтованого культурно-історичного розподілу раннього східного епіграветту цього регіону. Але необхідно зазначити, що за єдиною пам'яткою - Мізине - деякими дослідниками вже виділено окрему археологічну культуру.

3 точки зору аргументації можливого спільного етнічного походження східноепіграветтського населення цього регіону, російськими дослідниками вже зроблено

19 Лисицын С.Н. Эпиграветт или постграветт? // Stratum plus. 1999. № 1. С. 119. 
важливі кроки 20 . Встановлена значна схожість між індустріями стоянок Борщеве I та Мізин, що дало підстави М.В. Аніковичу зробити навіть висновок про їх однокультурність ${ }^{21}$. Л.М. Тарасов вбачав схожість між індустріями стоянок Єлісеєвичі I, Косиця та Коршеве II22. Найближчу аналогію індустрії стоянки Супоневе Н.А. Хайкунова вбачає в індустрії стоянки Мізин 23 . Встановлена типологічна близькість між індустріями стоянок Єлісеєвичі I та Юровичі 24 . Індустрійна спадковість між цими пам'ятками та деснянською культурою для російських фахівців також є очевидною.

Час існування у деснянському регіоні цього сумарного ранньоепіграветтського населення припадає, за рядом факторів, на хронологічний відрізок у 19/18-16/15 тисяч років тому. Нащадки цього ранньоепіграветтського населення продовжували мешкати у Подесенні та пізніше, на часовому відрізку 15-13 тисяч років тому. Але воно було значною мірою консолідовано в одну культурно-історичну спільноту. Автор вважає їх носіями подальших традицій деснянської археологічної культури. Це населення розширило територіальні рамки мешкання на схід (у Верхнє Подоння), на південний схід (до Оки) та на південний схід (на Сіверський Донець). У цей же період між Десною та Верхнім Доном мешкали носії інших культурних традицій, з деякими рисами близькості до деснянської матеріальної культури - Курськ I, Курськ II, Бики та деякі інші.

Таким чином, можна зробити узагальнюючий висновок - за усіх різких змінах або поступовому розвитку індустрій східного епіграветту деснянсько-донського регіону відбувалися процеси змін матеріальної культури населення. Але, судячи з усього, не відбувалося кардинальної зміни самого населення. Цей висновок підтверджується ще й тим, що в інших регіонах Східної Європи населення з аналогічною матеріальною культурою сучасній науці невідомо.

Фінально-епіграветтські пам'ятки у деснянсько-донському регіоні поки що не виявлені. Фінальний палеоліт тут представлений зовсім індустрійно іншими пам'ятками - типу лінгбі, аренсбург і свідер. Можна впевнено зазначити, що після 13 тисяч років тому тут відбувається повна зміна населення за рахунок нових мисливців, мігрантів із заходу, що спеціалізувалися, переважно, на полюванні на північного оленя.

За даними проведеного культурно-історичного аналізу археологічних джерел можна зробити й загальний висновок. А саме - деснянсько-донський регіон було заселено постійно (від 23 до 13 тисяч років тому) населенням єдиного центральноєвропейського походження. Це населення пройшло у своєму етноісторичному розвитку кілька етапів, саме через розвиток матеріальної культури східнограветтського - східно-епіграветтського типів. У цьому ж регіоні зародився й увесь пласт східного епіграветту, як такого. Звідси відбулося розселення східноепіграветтського населення просторами Східної Європи. 3 утворенням в інших при-

\footnotetext{
20 Оленковський М.П. Соціально-історичний аспект «археологічної культури» доби пізнього палеоліту // Археологический альманах. № 13. Донецк, 2003. С. 250-254.

21 Аникович М.В. «Восточный граветт» и проблема миграций в верхнепалеолитическую эпоху // Восточный граветт. - Тез. докл. международного коллоквиума. Москва, 1997. С. 10-13.

22 Тарасов Л.М. Позднепалеолитическая стоянка Косица // КСИА. Вып. 165. Москва: Наука, 1981. C. $50-55$.

23 Хайкунова Н.А. Кремневый инвентарь стоянки Супонево (и ее место в палеолите бассейна Десны): Автореф. дис... к-та истор. наук: 07.00.06 / Моск. гос. ун-т. Москва, 1985. 19 с.

24 Лисицын С.Н. Эпиграветт или постграветт? С. 97
} 
родних умовах цих нових територій вже того східно-епіграветтського різноманіття, яке відоме сучасній науці. Відтак, якщо Східне Прикарпаття було «колискою» усього класично-епіграветтського населення Східної Європи, то деснянсько-донський регіон був «колискою» усього східно-епіграветтського населення.

На підставах здійсненого археологічного аналізу, наданого вище, автор пропонує наступну реконструкцію процесів розселення та засвоєння території півдня та південного сходу Східної Європи населенням - носіями східноепіграветтських традицій у матеріальній культурі. Археологічні джерела дозволяють зробити висновок, що у часи холодного піку останнього льодовикового періоду (Вюрм 3) частина мешканців деснянського регіону, носії пізніх східно-граветтських традицій матеріальної культури (типу індустрій пам'яток Пушкарі I, Погон, або Мізин), здійснили значне переміщення на південь, досягнувши біля 18 тисяч років тому районів ПівнічноСхідного та Східного Причорномор'я.

Можна було б припустити й можливість поширення на південь не населення, а ідей і традицій граветтського шляху розвитку. Але це зробити практично неможливо. Адже повністю відсутні дані хоч про якесь заселення території між деснянськодонським регіоном і Північним Кавказом у період між 19 і 17 тисячами років тому. Місцеве епіорін'якське населення на цей час вже зникло з історичної арени, та й за своїми індустрійними традиціями воно не могло виконувати ці посередницькі функції. Хоч якісь сліди мешкання місцевого ранньоепіграветтського населення тут не виявлено. Відтак, був відсутнім проміжний ланцюг для «транспортування» технологічних і типологічних винаходів в інші регіони та, відповідно, для формування інакших культурно-історичних традицій.

Аналіз археологічних джерел дозволяє передбачити, що саме контактування місцевого (західно-кавказького) та прийшлого (деснянсько-верхньодонського) населення утворило нове етно-історичне явище, носії якого залишили сучасній науці археологічні джерела імеретинської археологічної культури. Ця археологічна культура, на етапі появи та раннього розвитку, являла собою злиття індустрій орін'якського та граветтського шляхів розвитку, з утворенням своєрідної східноепіграветтської індустрії.

3 періодом потепління Ляско (17-16 тисяч років тому) носії індустрійних традицій імеретинської культури починають просування на північний захід, уздовж берега Чорного моря й по долині Дону (що тоді протікав по рівнині осушеної регресією улоговини Азовського моря). В районі сучасного устя Дону, з нез'ясованих ще причин, біля 16 тисяч років тому складається (на базі матеріальної культури імеретинського населення) дещо відмінна індустрія нового східно-епіграветтського типу матеріальна культура носіїв кам'янобалківської археологічної культури.

Приблизно у той час носії імеретинських традицій проникають на територію сучасного Кримського півострова, який тоді не був півостровом, а був частиною суші. Тут засновуються традиції верхньосюренської східно-епіграветтської археологічної культури 25.

Біля 15,5-15 тисяч років тому відбувається просування носіїв кам'янобалківської культури на захід, майже до сучасних Присивашшя, Нижнього Подніпров'я та Дніпровського Надпоріжжя. Тут складається етноісторичне співтовариство людей, що

25 Оленковский Н.П. Эпиграветт Восточной Европы. Культурно-исторический аспект. С. 301-311. 
заклали традиції східно-епіграветтської північно-приазовської археологічної культури ${ }^{26}$.

Пізніше, в долині Сіверського Донця, склалася ще одна східно-епіграветтська археологічна культура (представлена рогаликськими пам'ятками), близька за індустрією як до верхньосюренської, так і до північно-приазовської археологічної культури ${ }^{27}$. Але найбільш достовірними її засновниками, найвірогідніше, були носії традицій кам'янобалківської археологічної культури.

Аналіз матеріальної культури носіїв межирицької східно-епіграветтської культури свідчить, що вона утворилась саме в Середньому Подніпров'ї, біля 15 тисяч років тому28. Скоріш за все, це $\epsilon$ наслідком контактів між представниками деснянської та східно-приазовської східно-епіграветтської культур. Про це свідчить індустрія межирицької археологічної культури, з елементами обох зазначених археологічних культур, але з переважанням традицій північно-приазовської. У будівництві ж жител з кісток мамонтів і за фауністичним складом мисливської здобичі - аналогії $є$ в деснянській культурі 29 . Можна припустити, що представники північно-приазовської культури 3 Надпоріжжя, просунулись на північ, у Середнє Подніпров'я (в регіон з більш холодним кліматом та іншим складом мисливської здобичі). Тут змушені були запозичити у більш північних сусідів (носіїв деснянської культури) не тільки методи полювання на мамонтів, але й більш теплу та надійну конструкцію житлових споруд.

На завершення можна зазначити, що населення Східної Європи, носії різних культур східного епіграветту, не зникло з історичної арени безслідно. Воно приймало участь у складенні декількох фінальнопалеолітичних і ранньомезолітичних культур цієї частини континенту. Риси східного епіграветту простежуються, як мінімум, в

\footnotetext{
26 Оленковський М.П. Пізній палеоліт Нижньодніпровського регіону у світлі радіовуглецевого датування // Археологія та етнологія Східної Європи: матеріали і дослідження. Одеса: Астропринт, 2000. С. 185-196; Оленковський М.П. Північно-приазовська пізньопалеолітична культура // Археологія. 2001. № 3. С. 3-16; Оленковский Н.П. О происхождении и развитии североприазовской позднепалеолитической культури // Stratum Plus. 2001-2002. № 1 C. 383-292; Olenkovskiy M. Upper Palaeolithik of the Sivash Region // The Use of Living Space in Prehistory. Papers from a session held at the European Association of Archaeologists Sixth Annual Meeting in Lisbon 2000. Oxford, 2004. P. 51-59; Olenkovskiy M. The Eastern Epigravettian in the North Azov region (Ukraine) // Atti Soc. Preist. Protost. Friuli. V.G., Trieste. XVII. 2008-2009 (2010). P. 7-26.

27 Оленковський М.П. Історичні процеси на території Південної України 20-11 тисяч років тому // Актуальні проблеми історії та культури України. Ч. І. Миколаїв-Одеса: Тетра, 2000. С. 4-12.

${ }^{28}$ Нужний Д.Ю. Верхньопалеолітичні пам'ятки типу Межиріч та їхнє місце серед епіграветтських комплексів Середнього Дніпра // Кам'яна доба України. Київ: Шлях, 2002. С. 57-81.

29 Оленковский Н.П. О каменнобалковской подоснове северо-приазовской и межирицкой позднепалеолитических культур // Труды научн. конф. «Проблемы археологии Юго-Восточной Европы». Ростов-на-Дону, 1998. С. 20-21; Оленковський М.П. Східний гравет, епігравет та граветійський шлях розвитку в пізньому палеоліті України // Археологія. 2000. № 2. С. 57-64; Оленковський М.П. Культурно-історичні процеси в середню та пізню пори пізнього палеоліту Лівобережної України // Археологический альманах. № 9. Донецк, 2000. С. 81-88; Оленковский Н.П. Центральноевропейский эпиграветт и восточноэпиграветтийские культуры Украины // Stratum Plus. 2000. № 1. С. 368-377; Оленковський М.П. Північно-приазовська пізньопалеолітична культура; Оленковський М. До виділення археологічних культур східного епіграветту на теренах України // Записки наукового товариства імені Шевченка. Праці Археологічної комісії. T. CCXLIV. Львів, 2002. C. 44-65; Оленковский Н.П. О происхождении и развитии северо-приазовской позднепалеолитической культуры; Оленковський М. Пізньопалеолітичні культури Лівобережної України // Археологія Тернопільщини. Тернопіль: Джура, 2003. С. 23-32; Оленковський М.П. Деснянська східноепіграветтська культура в українському Подесенні // Кам'яна доба України. Вип. 4. Київ-Полтава: Шлях, 2003. С. 256-261.
} 
індустріях фінальнопалеолітичних осокорівської та шан-кобинської культур на території України, а також фінальнопалеолітичних - початково-мезолітичних культур Східного Причорномор'я.

У плані з'ясування подальшої історичної долі східно-епіграветтського населення $\epsilon$ проблема, що потребує додаткової наукової розробки. Стосується це наявності у центрі та на півдні Східної Європи археологічних культур фінального епіграветту. Які, як відомо, мали широкий розвитоку Південній Європі. Згідно традицій розвитку південно-європейського епіграветту (з наявністю як виробів з притупленим краєм, так й геометричних мікролітів різних форм), у Східній Європі до фінального епіграветту можна було б віднести такі фінальнопалеолітичні пам'ятки, як Леонтівка, Прогон, а також Рогалик II, Рогалик IV, Передільське I. Ці стоянки відносяться одними археологами до осокорівської археологічної культури, іншими - до рогаликцаринківської єдності. Не вдаючись до полеміки щодо правоти цих підходів, можна однак стверджувати, що це культурно-історичне явище базується на пізньому епіграветті, представленому рогалик-передільською та північно-приазовською східноепіграветтськими археологічними культурами ${ }^{30}$

\section{REFERENCES}

Anikovich, M.V. (1997). «Vostochnyi gravett» i problema migracii v verhnepaleoliticheskuiu epohu [«East Gravett» and the Problem of Migration in the Upper Paleolithic Age]. Abstracts of Papers: Vostochnyj gravett (pp. 10-13). Moskva [in Russian].

Borziyak, I.A. (1990). Rashkovskaia, akkarzhanskaia i anetovskaia pozdnepaleoliticheskie kultury na Yugo-Zapade SSSR [Rashkov, Akkarzha and Anetov Late Paleolithic cultures in the South-West of the USSR]. Abstracts of Papers: Problemy pervobytnoi arheologii Severnogo Prichernomoria (pp. 18-20). Herson [in Russian].

Haikunova, N.A. (1985). Kremniovyi inventar stoianki Suponevo (i yeio mesto v paleolite basseina Desny) [Flint inventory of the Suponevo site (and its place in the paleolithic of the Desna basin)]. (Extended abstract of Candidate's thesis). Moskva [in Russian].

Chirica, V. (1989). The Gravettian in the East of the Romanian corpathians. Jassy.

Chirica, V. (1991). Le Gravettien en Roumanie. Le Paleolithique et le Neolithique de la Roumanie en contexte (pp. 7-15). Jasi.

Kovalenko, S.I. \& Ketraru, N.A. (1999). Nekotorye osobennosti razvitiya verhnepaleoliticheskih industrii v dnestrovskoi zone Moldavii [Some peculiarities of the development of the Upper Palaeolithic industries in the Dniester region of Moldova]. Stratum plus, 1, 168-195 [in Russian].

Krotova, 0.0. (2000). Hravettoidni kompleksy Pivnichnoho Prychornomoria [Gravettoid complexes of the Northern Black Sea coast]. Arkheolohiia, 2, 30-37 [in Ukrainian].

Lisitsyn, S.N. (1999). Epigravett ili postgravett? Osobennosti kremnevogo inventaria pozdnevaldaiskikh pamiatnikov s mamontovym khoziaistvom [Epigravettian or Postgravettian? Characteristics of flint inventories of the Late Valdai sites with mammoth economic]. Stratum plus, 1, 83-120 [in Russian].

Nuzhnyi, D.Yu. (2002). Verkhnopaleolitychni pamiatky typu Mezhyrich ta yikhne mistse sered epihravettskykh kompleksiv Serednoho Dnipra [Upper Paleolithic site Mezhyrich type and their place among the epigravet complexes of the Middle Dnieper region]. Kamiana doba Ukrainy (pp. 5781). Kyiv: Shliakh [in Ukrainian].

Olenkovskij, N.P. (1991). Pozdnii paleolit i mezolit Nizhnego Dnepra [Late Paleolithic and Mesolithic of the Lower Dnieper region]. Herson [in Russian].

Olenkovskij, N.P. (1998). O kamennobalkovskoi podosnove severo-priazovskoi i mezhirickoi pozdnepaleoliticheskih kultur [About the Kamenna Balka sub-base of the North-Azov and Mezhirich culture of Upper Paleolithic]. Abstracts of Papers: Problemy arheologii Yugo-Vostochnoi Evropy (pp. 20-21). Rostov-na-Donu [in Russian].

Olenkovskij, N.P. (2001-2002). O proiskhozhdenii i razvitii severo-priazovskoi pozdnepaleoliticheskoi kultury [On Origin and Development of North Azov Late Palaeolithic Culture]. Stratum Plus, 1, 383292 [in Russian].

30 Оленковський М.П. Кавказька складова у фінальному палеоліті та мезоліті Південної України // Археологія. 1996. № 3. С. 74-85. 
Olenkovskij, N.P. (2003-2004). Nizhnedneprovskaia epigravettskaia kultura [Nizhnedniprovska (Lower Dnieper) Epigravettian Culture]. Stratum Plus, 1, 307-333 [in Russian].

Olenkovskij, N.P. (2008). Epigravett Vostochnoi Evropy. Kulturno-istoricheskij aspekt [Epigravett of Eastern Europe. Cultural and historical aspect]. Herson [in Russian].

Olenkovskij, N.P. (2009). Epigravettskaia stoianka Dmytrivka [Epigravett site Dmytrivka]. Herson: Ailant [in Russian].

Olenkovskij, N.P. (2014). 0 puti razvitia odnoi iz grupp pozdnepaleoliticheskih pamiatnikov Priazovia [About the path of development of one of the groups of Late Paleolithic monuments of the Sea of Azov region]. Kamennyi vek: ot Atlantiki do Pacifiki: Zamiatninskii sbornik, 3. (pp. 211-220). SanktPeterburg [in Russian].

Olenkovskij, N. (2017). Epigravett Vostochnoi Evropy. Metodologiia issledovanii i konkretno-istoricheskie rekonstrukcii [Epigravett of Eastern Europe. Research Methodology and Specific Historical Reconstructions]. Herson: Ajlant [in Russian].

Olenkovskyi, M.P. (1996). Kavkazka skladova u finalnomu paleoliti ta mezoliti Pivdennoi Ukrainy [Caucasian component in the final Paleolithic and Mesolithic of Southern Ukraine]. Arkheolohiia, 3, 74-85 [in Ukrainian].

Olenkovskyi, M.P. (1997). Kulturno-istorychni protsesy v piznomu paleoliti ta mezoliti Prysyvashshia [Cultural and historical processes in the Upper Paleolithic and Mesolithic of Sivash region]. In: S.A. Bulatovich (Ed.). Arheologiia i etnologiia Vostochnoi Evropy (pp. 103-112). Odessa [in Ukrainian].

Olenkovskiy, M. (2004). Upper Palaeolithik of the Sivash Region. In The Use of Living Space in Prehistory. Papers from a session held at the European Association of Archaeologists Sixth Annual Meeting in Lisbo (pp. 51-59). Oxford.

Olenkovskiy, M. (2010). The Eastern Epigravettian in the North Azov region (Ukraine). Atti Soc. Preist. Protost. Friuli-V.G., Trieste, XVII, 7-26.

Olenkovskyi, M.P. (2000). Istorychni protsesy na terytorii Pivdennoi Ukrainy 20-11 tysiach rokiv tomu [Historical processes in the territory of Southern Ukraine 20-11 thousand years ago]. Aktualni problemy istorii ta kultury Ukrainy (Vol. I, pp. 4-12). Mykolaiv-Odesa: Tetra [in Ukrainian].

Olenkovskyi, M.P. (2000). Kulturno-istorychni protsesy v seredniu ta pizniu pory piznoho paleolitu Livoberezhnoi Ukrainy [Cultural and historical processes in the middle and late time Upper Paleolithic of the Left Bank of Ukraine]. Arkheolohycheskii almanakh, 9 (pp. 81-88). Donetsk [in Ukrainian].

Olenkovskyi, M.P. (2000). Paleolit ta mezolit Prysyvashshia: Problemy epihravetu Ukrainy [Paleolith and Mezolit Prysyvashshia. The problems of Epihravettian of Ukraine]. Kherson: Prydniprovia [in Ukrainian].

Olenkovskyi, M.P. (2000). Piznii paleolit Nyzhnodniprovskoho rehionu u svitli radiovuhlytsevoho datuvannia [Upper Paleolithic of the Lower Dnieper region in the light of radiocarbon dating]. In: V.N. Stanko (Ed.). Arkheolohiia ta etnolohiia Skhidnoi Yevropy: materialy i doslidzhennia (pp. 185196). Odesa: Astroprynt [in Ukrainian].

Olenkovskyi, M.P. (2000). Skhidnyi hravet, epihravet ta hravetiiskyi shliakh rozvytku v piznomu paleoliti Ukrainy [Eastern Gravet, Epigravet and the Gravetian path of development in the late Paleolithic of Ukraine]. Arkheolohiia, 2, 57-64 [in Ukrainian].

Olenkovskyi, M.P. (2001). Epihravettski ta skhidnoepihravettski kultury Ukrainy [Epigravet and eastern epigravet cultures of Ukraine]. Vita Antiqua, 3-4. Kyiv: Stylos, 149-155 [in Ukrainian].

Olenkovskyi, M.P. (2001). Pivnichno-pryazovska piznopaleolitychna kultura [North Azov culture of Upper Paleolithic]. Arkheolohiia, 3, 3-16 [in Ukrainian].

Olenkovskyi, M. (2002). Do vydilennia arkheolohichnykh kultur skhidnoho epihravettu na terenakh Ukrainy [To the selection of archaeological cultures of the Eastern epigravet on the territory of Ukraine]. Zapysky naukovoho tovarystva imeni Shevchenka. Pratsi Arkheolohichnoi komisii. T. CCXLIV. Lviv, 44-65 [in Ukrainian].

Olenkovskyi, M.P. (2003). Desnianska skhidnoepihravettska kultura v ukrainskomu Podesenni [Desna Eastern Epigravet culture in the Ukrainian Desna region]. Kamiana doba Ukrainy, 4. Kyiv-Poltava: Shliakh, 256-261 [in Ukrainian].

Olenkovskyi, M.P. (2003). Sotsialno-istorychnyi aspekt «arkheolohichnoi kultury» doby piznoho paleolitu [Socio-historical aspect of the «archaeological culture» of the period of the Upper Paleolithic]. Arkheolohycheskii almanakh, 13 (pp. 250-254). Donetsk [in Ukrainian].

Olenkovskyi, M. (2003). Piznopaleolitychni kultury Livoberezhnoi Ukrainy [Upper Paleolithic cultures of the Left Bank of Ukraine]. Arkheolohiia Ternopilshchyny (pp. 23-32). Ternopil: Dzhura [in Ukrainian] 
Olenkovskyi, M. (2005). Oselivska epihravettska kultura [Oseliv epigravett culture]. Materialy $i$ doslidzhennia z arkheolohii Prykarpattia i Volyni, 9 (pp. 194-216). Lviv [in Ukrainian].

Tarasov, L.M. (1981). Pozdnepaleoliticheskaia stoianka Kosica [Upper Paleolithic site of Kositsa]. Kratkie soobscheniia Instituta arkheologii SSSR, 165 (pp. 50-55). Moskva: Nauka [in Russian].

\section{Mykola Olenkovskyi}

(Independent researcher, Kherson, Ukraine)

ORCID: https://orcid.org/0000-0003-3382-5263

\section{The Epigravettian of the Eastern Prikarpatty and the Epigravettian And the Eastern Epigravettian in Historical Development}

The Scientific Article considers the problems of the methodology of the research of the Epigravettian Eastern Europe population history. The unused yet opportunities of the research of the cultural and historical processes in the Upper Paleolithic Age by means of separation and research of archaeological cultures are demonstrated. The possibility of concrete historical reconstructions by way of the research of culture-historical processes is advocated

In his researches of the Upper Paleolithic Age the author holds the viewpoint that historical level of archeological researches is the objective element of the reality in the structure of the social system analysis. The author endorses the view of a number of researchers of the absence of such social society structure as the tribe as late as the Upper Paleolithic Age. On this basis, the author believes that every separate Epigravettian archeological culture can be the illustration of life activity only of a separate primitive society.

It is shown in the research that ethnographical sources can be used in historical and cultural reconstructions of the life of the Paleolithic hunters of Eastern Europe. However, the reconstructions only put forward hypotheses and are rather disputable.

It is the author's opinion that Eastern Europe saw both the Classic Epigravettian (similar to the Epigravettian of Central Europe) and the Eastern Epigravettian. The Eastern Epigravettian, in the author's judgment, is varied in material culture and origin. The Classic Epigravettian is spread in the limits of the Eastern Rumanian Carpathian Mountains, in Moldova and in the Right-Bank Ukraine. The Eastern Epigravettian exists in the Left-Bank Ukraine and in the south-west of the European part of the Russian Federation.

The questions of the ethno-cultural sources of origin of the Classic and the Eastern Epigrovettian of Eastern Europe are examined. The author made the conclusion that the Classic Eastern European Epigravettian grounds on the Central European Eastern Gravettian, spread in the Ukrainian Carpathian region. Whereas the Eastern Epigravettian originated from the Eastern Gravettian, developed in the regions of the Desna River and the upper reaches of the Don River.

The author's findings of investigation presenting the processes of origination and development of the archeological cultures of the Classic and the Eastern Epigravettian of Eastern Europe are given in the Article.

Dispersal routes of hunting communities, the representatives of these archeological cultures, are reconstructed as well.

Keywords: Upper Paleolithic, classic Epigravettian, eastern Epigravettian, archaeological culture, flint industry 